Article

\title{
Straw Incorporation Management Affects Maize Grain Yield through Regulating Nitrogen Uptake, Water Use Efficiency, and Root Distribution
}

\author{
Pengxiang Sui ${ }^{1}$, Ping Tian ${ }^{1}{ }^{1}$, Hongli Lian ${ }^{1}$, Zhengyu Wang ${ }^{1}$, Ziqi Ma ${ }^{1}$, Hua Qi ${ }^{1, *}$, Nan Mei ${ }^{2}$, \\ Yue Sun ${ }^{1}$, Yingyan Wang ${ }^{1}$, Yehan $\mathrm{Su}^{1}{ }^{1}$, Guangxin Meng ${ }^{1}$ and Ying Jiang ${ }^{1, *}$ \\ 1 College of Agronomy, Shenyang Agricultural University, Shenyang 110866, China; \\ suipengxiang@stu.syau.edu.cn (P.S.); tianping23@stu.syau.edu.cn (P.T.); 2019200057@stu.syau.edu.cn (H.L.); \\ wangzhengyu27@stu.syau.edu.cn (Z.W.); 2018240174@stu.syau.edu.cn (Z.M.); \\ 2017220244@stu.syau.edu.cn (Y.S.); wangyingyan@stu.syau.edu.cn (Y.W.); \\ 2017220228@stu.syau.edu.cn (Y.S.); 20172202241@stu.syau.edu.cn (G.M.) \\ 2 College of Agronomy, Jilin Agricultural University, Changchun 130118, China; meinan413@163.com \\ * Correspondence: qihua10@syau.edu.cn (H.Q.); jiangying@syau.edu.cn (Y.J.); Tel.:+86-024-88487135
}

Received: 28 January 2020; Accepted: 25 February 2020; Published: 27 February 2020

\begin{abstract}
Returning crop straw to soil can potentially improve soil health and crop production, facilitating sustainable agriculture. However, the effects of straw incorporation with various tillage management techniques combined with nitrogen $(\mathrm{N})$ regimes on crop root growth, and water and $\mathrm{N}$ utility are not well understood. In this study, rotary tillage (RTS) and plow tillage (PTS) for straw incorporation combined with $\mathrm{N}$ regimes (CK, no $\mathrm{N}$ applied; LN, $112 \mathrm{~kg} \mathrm{~N}^{-1}$; $\mathrm{MN}, 187 \mathrm{~kg} \mathrm{~N}$ $\mathrm{ha}^{-1}$; and $\mathrm{HN}, 262 \mathrm{~kg} \mathrm{~N} \mathrm{ha}^{-1}$ ) were used to determine their effects on soil water and mineral $\mathrm{N}$ availability, root distribution, crop $\mathrm{N}$ uptake, grain yield, and water use efficiency (WUE) of maize in northeast China. The results demonstrate that higher levels of pre-sowing soil-water storage and field evapotranspiration (ET), and lower levels of WUE and pre-sowing soil mineral N storage (Nmin-PS) at a depth of $0-60 \mathrm{~cm}$ were obtained with the RTS treatments as compared to the PTS treatments. $\mathrm{N}$ addition improved Nmin-PS and post-harvest soil mineral $\mathrm{N}$ storage (Nmin-PH) at a depth of 60-100 cm in 2016, and increased WUE compared to CK. RTS treatments enhanced root weight density (RWD) at a depth of 0-60 cm in 2016-2017, root length density (RLD), ratio of root length density (RLDR), and ratio of root weight density (RWDR) at a depth of 30-60 cm in 2016, and RLD at a depth of 0-30 cm in 2017. N addition promoted RLD and RWD at a depth of 0-10 cm in 2016-2017. RTS treatments reduced pre-silking shoot $\mathrm{N}$ uptake (NPS) and grain yield. Shoot $\mathrm{N}$ uptake and grain yield were enhanced in response to increasing levels of $\mathrm{N}$; however, the grain yield did not show further significant improvements when the amount of $\mathrm{N}$ applied was over $187 \mathrm{~kg} \mathrm{~N} \mathrm{ha}^{-1}$ (except for RTS in 2016). Overall, tillage with straw incorporation management and $\mathrm{N}$ levels markedly affected the soil physicochemical properties (such as ET, Nmin-PS, and Nmin-PH). This influenced grain yield indirectly by further mediating root traits (RLD, RWD, RLDR, and RWDR) with consequences for the NPS and post-silking shoot N uptake (NPOS) of maize, which were found to have greatest direct and positive impact on maize grain yield.
\end{abstract}

Keywords: straw incorporation; root distribution; crop N uptake; WUE; grain yield

\section{Introduction}

China produces a huge amount of crop straw, with a yield of 598 million tons in 2014; however, more than $30 \%$ of crop straw is burned in the field in the eastern and southern regions, which has become a significant seasonal source of air pollution [1-3]. Therefore, finding an efficient, low cost, and 
less polluting use for crop straw is an urgent issue in China [4]. Currently, direct straw incorporation to the soil as fertilizer is the most extensively adopted approach in many developed countries. This not only protects the environment, but also improves soil health and contributes to sustainable food production [5-7]. Meanwhile, straw incorporation alleviates soil erosion and runoff, improves soil aggregation, and promotes the increase of soil microbial activity than straw burning and/or removal $[5,6]$. However, the high $\mathrm{C} / \mathrm{N}$ ratio of cereal crop straw may reduce mineral $\mathrm{N}$ availability and might affect microbial decomposition of crop straw [8,9]. Thus, exploring the effects of straw incorporation on soil $\mathrm{N}$ utility, particularly soil mineral $\mathrm{N}$, has become an important topic [10].

Soil water storage significantly affects mineral $\mathrm{N}$ mobility, which is largely modulated by precipitation and irrigation [11]. Therefore, how to increase soil water storage in rainfed conditions, especially in the dry season, is the key to higher crop yields [12]. Straw incorporation into the soil is a great approach to enhance the soil water storage capacity in the subsoil layers, which also reduce soil evaporation [13]. In addition, previous studies have shown that, compared to shallow tillage, deep tillage coupled with straw incorporation (to a depth $>20 \mathrm{~cm}$ ) can reduce soil bulk density [14], increase soil porosity and hydraulic conductivity $[15,16]$, thus provide a more favorable soil physical environment for crop root growth [17].

Root systems play a pivotal role in soil water and mineral $\mathrm{N}$ extraction. Root growth and distribution in the soil are greatly regulated by field management techniques (e.g., tillage with straw incorporation practices or $\mathrm{N}$ application) $[18,19]$. It is reported that deep tillage with straw incorporation increases root mass density to a depth of $60 \mathrm{~cm}$ compared with shallow tillage in a sandy loam soil due to lower penetration resistance and superior quantity of soil water storage [13]. Furthermore, Guan et al. [18] concluded that plow tillage on a light loam soil enhanced root length density at a depth of $20-50 \mathrm{~cm}$ compared with rotary tillage (RTS). However, rotary tillage and plow tillage were found to have similar root length densities in the $0-60 \mathrm{~cm}$ soil layer in a clay loam soil [20]. However, effects of tillage with straw incorporation practices on root growth and distribution are variable, depending on soil texture. $\mathrm{N}$ application improved the root length density in the entire soil layer compared with no $\mathrm{N}$ treatment, which increased the proportion of root length density in the $0-40 \mathrm{~cm}$ soil layer and decreased the proportion of root length density in the $40-120 \mathrm{~cm}$ soil layer [21]. However, root growth might reach its maximum value at the optimum $\mathrm{N}$ rate [22]. It was reported that the maximum root length of maize was associated with an $\mathrm{N}$ rate of $240 \mathrm{~kg} \mathrm{~N} \mathrm{ha}^{-1}$, an improvement of $7.4 \%$ and $11.7 \%$ compared with that of $168 \mathrm{~kg} \mathrm{~N} \mathrm{ha}^{-1}$ and $312 \mathrm{~kg} \mathrm{~N} \mathrm{ha}^{-1}$, respectively [23]. Moreover, modeling studies concluded that deeper root phenotypes would enhance soil water and $\mathrm{N}$ acquisition [24,25]. Accordingly, the 'steep, cheap, and deep' root traits of the ideotype might increase water and $\mathrm{N}$ acquisition by enhancing subsoil foraging in the drought season or leaching environments [26,27].

Root growth and the amount of $\mathrm{N}$ uptake are coordinated with shoot growth and demand for N [28]. Meanwhile, root growth is closely related with the supply of photosynthates from the shoot $[29,30]$. Thus, there is competition between the root sink and the shoot sink, especially under low $\mathrm{N}$ input [31,32]. On the other hand, the amount of $\mathrm{N}$ uptake in an environment of sufficient $\mathrm{N}$ supply is determined by the shoot growth potential, and not by the root size [28]. Moreover, the grain $\mathrm{N}$ originates from the $\mathrm{N}$ uptake in the vegetative and reproductive phases [31]. For example, in maize, $45-65 \%$ of the grain $\mathrm{N}$ is transferred from the $\mathrm{N}$ in the stover before silking, and the remainder from post-silking $\mathrm{N}$ uptake [33]. Notably, these results suggest that to seek an optimized tillage with straw incorporation and an $\mathrm{N}$ regime, one should consider root size, $\mathrm{N}$ uptake, and grain yield.

Although previous studies have focused on the effect of tillage with straw incorporation on increasing grain yield and improving soil properties, as well as the correlation between $\mathrm{N}$ application and root system characteristics [5,21,34], little is known about the maize root system, $\mathrm{N}$ uptake, and grain yield under different tillage systems with straw incorporation and $\mathrm{N}$ regimes. The objectives of this study were i) to determine the effects of rotary tillage and plow tillage (PTS) with straw incorporation practices and $\mathrm{N}$ fertilization on soil water, mineral $\mathrm{N}$ storage, and water use efficiency (WUE); ii) to investigate the root traits, crop $\mathrm{N}$ uptake, and grain yield of maize under different tillage 
systems with straw incorporation and $\mathrm{N}$ regimes; iii) to clarify the regulation relationship between tillage technique with straw incorporation and applied $\mathrm{N}$ levels and maize grain yield.

\section{Materials and Methods}

\subsection{Site Description}

This study was conducted in Tieling City, Liaoning Province, China $\left(42^{\circ} 49^{\prime} \mathrm{N}, 124^{\circ} 16^{\prime} \mathrm{E}\right)$. Maize (Zea mays L.) is the dominant crop planted in this area, with one harvest per year. The climate in this area is subtropical arid, characterized by large monthly fluctuations in precipitation, and the cumulative precipitation during 2016 and 2017 were 811.4 and $333.8 \mathrm{~mm}$, respectively, during the growing period (Figure 1). Meanwhile, the monthly mean temperatures were steady, around $20.9^{\circ} \mathrm{C}$ Before sowing in 2015, the chemical properties of the soil (0-20 cm in depth) at the experimental site were: $15.7 \mathrm{~g} \mathrm{~kg}^{-1}$ organic matter, $1.2 \mathrm{~g} \mathrm{~kg}^{-1}$ total $\mathrm{N}, 25.7 \mathrm{mg} \mathrm{kg}^{-1}$ available $\mathrm{P}, 29.3 \mathrm{mg} \mathrm{kg}^{-1}$ available $\mathrm{K}$, and $\mathrm{pH} 5.64$.

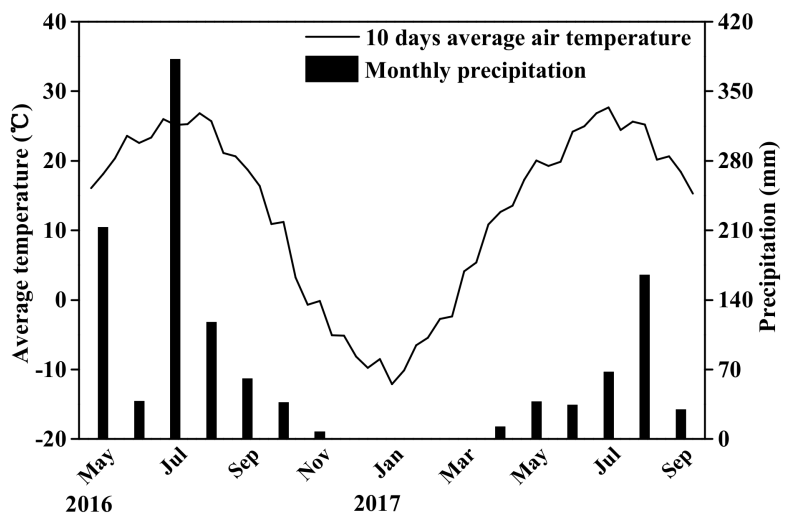

Figure 1. Monthly precipitation (mm) and ten days average air temperature $\left({ }^{\circ} \mathrm{C}\right)$ from May 2016 to September 2017.

\subsection{Experimental Design}

Experiments were performed in 2015-2017 using a split plot experimental design with three replicates. Two tillage approaches (rotary-till and plow-till) were employed for the main plots and four $\mathrm{N}$ levels were $0 \mathrm{~kg} \mathrm{~N}^{-1}$ (control, CK), $112 \mathrm{~kg} \mathrm{~N} \mathrm{ha}^{-1}$ (low $\mathrm{N}$ application, $\mathrm{LN}$ ), $187 \mathrm{~kg} \mathrm{~N}^{-1}$ (medium $\mathrm{N}$ application, $\mathrm{MN}$ ), and $337 \mathrm{~kg} \mathrm{~N}^{-1}$ (high $\mathrm{N}$ application, $\mathrm{HN}$ ) for the subplots. The main plot size was $36 \times 10 \mathrm{~m}$, which was split into four subplots of $9 \times 10 \mathrm{~m}$.

Air-dried maize straw and residues were chopped into $5-10 \mathrm{~cm}$ in length after harvest in 2015 and 2016. Then, tillage practices were conducted to incorporate maize straw into the soil, the rotary-till (RT) mixed the soil twice using a rotary tiller (1GKN-240, China) and incorporated the straw into the 0-15 cm soil layers (RTS), the plow-till (PT) inverted the soil to a depth of $30 \mathrm{~cm}$ with a plow (1L-525, China) and buried maize straw (PTS) into the soil.

Spring maize (Zhengdan 958) was planted manually with 67,500 plants $\mathrm{ha}^{-1}$ with a $60 \mathrm{~cm}$ row space during early May, and harvested at the end of September in each year. As for fertilizer management, both $\mathrm{P}$ (superphosphate) and $\mathrm{K}$ (potassium chloride) fertilizers were used as start fertilizers, and applied at a rate of $90 \mathrm{~kg} \mathrm{P}_{2} \mathrm{O}_{5} \mathrm{ha}^{-1}$ and $90 \mathrm{~kg} \mathrm{~K}_{2} \mathrm{O} \mathrm{ha}^{-1}$ for all treatments in the sowing stage. The $\mathrm{N}$ fertilizers (urea) were applied with one-third of total $\mathrm{N}$ as start fertilizer, and the remainder was applied at jointing stage of maize. Other agricultural managements-such as pest, disease, and weed controls - were applied following the local practices for high-yield maize production. 


\subsection{Sampling and Measurements}

Before sowing and after harvest of the maize, soil bulk density and water content were determined using the core ring method according to Blake and Hartage [35]. Soil cores (5 $\mathrm{cm}$ internal diameter) were randomly taken to a depth of $100 \mathrm{~cm}$ at $10 \mathrm{~cm}$ increments from three random locations in each plot. Fresh soil samples were sieved through $2 \mathrm{~mm}$ mesh and stored at $4{ }^{\circ} \mathrm{C}$ to determine soil mineral nitrogen $\left(\mathrm{NO}_{3}{ }^{-}-\mathrm{N}\right.$ and $\left.\mathrm{NH}_{4}{ }^{+}-\mathrm{N}\right)$; these were extracted with a $2 \mathrm{M} \mathrm{KCl}$ solution for $1 \mathrm{~h}$, then quantified by a discrete analyzer (Westco SmartChem 200) [36]. Soil water storage and soil mineral nitrogen storage were calculated according to the description in Dong et al. [37].

In 2016 and 2017, maize roots were sampled in the silking stage. The aboveground plant was cut close to the ground, and then a $24.7 \mathrm{~cm}$ (plant spacing) $\times 60.0 \mathrm{~cm}$ (row spacing) $\times 60.0 \mathrm{~cm}$ (soil depth) of soil mass with a central maize root was separated into six depth at $10 \mathrm{~cm}$ increments, then each layer was collected for root sampling. Each soil cuboid was placed in a nylon bag with $0.5 \mathrm{~mm}$ mesh to wash the soil and organic debris off roots. Then, images of the roots were captured using an Epson V700 scanner (Seiko Epson Corp, Japan) and analyzed with the WinRHIZO 2013 software (Regent Instruments, Canada Inc.) as described by Mu et al. [13]. Root dry weight was determined after drying

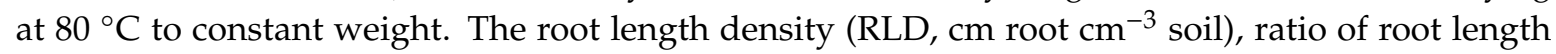
density (RLDR, \%), root weight density (RWD, $\mathrm{mg}$ root $\mathrm{cm}^{-3}$ soil), and ratio of root weight density (RWDR, \%) were calculated according to previous studies [11,13,21].

Shoots were collected from three randomly selected maize plants in the silking and maturity stages, dried to a constant weight at $80^{\circ} \mathrm{C}$, then finely ground for $\mathrm{N}$ content analysis. $\mathrm{N}$ content in the shoots was determined using the Kjeldahl method, as described in Nelson and Somers [38].

$$
\mathrm{N} \text { uptake pre-silking (NPS) = shoot } \mathrm{N} \text { uptake in the silking stage; }
$$

$\mathrm{N}$ uptake post-silking $(\mathrm{NPOS})=$ shoot $\mathrm{N}$ uptake in the maturity stages $-\mathrm{NPS}$.

The grain yield of the maize was determined by harvesting the middle six rows of each plot. Grains were separated from the air-dried cob. The moisture content of the grain was determined with a professional grain moisture measuring instrument (K.T.PM-8188-A, Japan). Maize grain yield was standardized to $14 \%$ of the moisture content.

\subsection{Calculations}

The field evapotranspiration (ET) during the whole season was calculated according to the water balance equation described in [11]

$$
\mathrm{ET}=\mathrm{P}+\mathrm{I}+\Delta \mathrm{SW}-\mathrm{R}-\mathrm{D}
$$

where $\mathrm{P}(\mathrm{mm})$ is the rainfall; $\mathrm{I}(\mathrm{mm})$ is irrigation amount (here, $\mathrm{I}=0)$; $\mathrm{R}(\mathrm{mm})$ is the surface runoff; $\mathrm{D}(\mathrm{mm})$ is the water drainage below the crop root zone. Both $\mathrm{R}$ and $\mathrm{D}$ were assumed to be of a negligible level in this study. $\triangle \mathrm{SW}(\mathrm{mm})$ was the soil water storage change from sowing to maturity. Thus, the water consumption was examined according to the equation

$$
\mathrm{ET}=\mathrm{P}+\Delta \mathrm{SW}
$$

Water use efficiency (WUE, $\mathrm{kg} \mathrm{ha}^{-1} \mathrm{~mm}^{-1}$ ) was calculated using the equation in [39]

$$
\text { WUE }=\text { grain yield/ET }
$$

\subsection{Statistical Analysis}

After verifying the homogeneity of error variances, all the data across tillage with straw incorporation practices, $\mathrm{N}$ levels, and years were pooled for analysis of variance with a three-factor 
variance analysis program using the ANOVA. Differences were compared using the Duncan's multiple range test at the 0.05 level of probability. All analyses were carried out using the analytical software package SPSS Statistics 23.0 software (SPSS Inc., Chicago, IL, USA), and all graphs were constructed using Origin 9.0 (OriginLab Inc., Northampton, MA, USA) software.

A structural equation model (SEM) was constructed to explore the direct and indirect impacts of soil physicochemical properties, root traits, and crop $\mathrm{N}$ uptake on maize yields. It was based on a multivariate approach using AMOS software (IBM SPSS AMOS 22.0). There were twelve predictors in the model: tillage with straw incorporation (tillage-straw), $\mathrm{N}$ level, field evapotranspiration (ET), soil mineral $\mathrm{N}$ storage in the $0-60 \mathrm{~cm}$ soil layer at pre-sowing (Nmin-PS) and post-harvest (Nmin-PH), root length density (RLD) and root weight density (RWD) in the 0-60 cm soil layer, ratio of root length density (RLDR) and ratio of root weight density (RWDR) in the 0-30 cm soil layer, plant $\mathrm{N}$ uptake at pre-silking (NPS) and post-silking (NPOS), as well as grain yield. The model fitting was assessed using the Chi-square statistic and its associated p-value, comparative fitting index (CFI), goodness-of-fit (GFI), and root mean square error of approximation (RMSEA).

\section{Results}

\subsection{Soil Mineral N Storage and Water Use Efficiency}

In addition to tillage with straw incorporation $(\mathrm{Ts}) \times \mathrm{N} \times$ year $(\mathrm{Y})$ in the post-harvest of maize, the significant effects on soil mineral $\mathrm{N}$ storage of maize at pre-sowing (Nmin-PS) and post-harvest (Nmin-PH) were found from Ts, N, and Y, as well as the interactions between them (Table 1). In 2016, in the 0-60 cm soil layer, Nmin-PS was increased with N application rate under PTS condition, compared to CK (Figure 2). Moreover, Nmin-PS and Nmin-PH in this soil layer under the PTS treatments were higher than those under RTS. However, in the $60-100 \mathrm{~cm}$ soil layer, regardless of the tillage technique with straw incorporation treatments, $\mathrm{N}$ application significantly improved Nmin-PS and Nmin-PH compared to CK. In 2017, Nmin-PS in the $0-60 \mathrm{~cm}$ and $60-100 \mathrm{~cm}$ soil layers were improved by N application under RTS and PTS; it also showed higher Nmin-PS under PTS than those under RTS.

Except for the $\mathrm{Y}$ factor, there were no consistent significant effects on soil water storage at pre-sowing and post-harvest. Water use efficiency (WUE) of the maize and field evapotranspiration (ET) were observed according to various factors and their interactions (Table 2). On average, soil water storage at pre-sowing and ET under RTS condition was significantly higher than those under PTS conditions in 2016 and 2017 (Table 2). However, PTS treatments improved WUE by 10.1\% in 2016 and $8.6 \%$ in 2017, compared to those under RTS treatments. With respect to N level management, there were no consistent effects on soil water storage at pre-sowing and post-harvest of maize in 2016. Except for the LN treatment under PTS conditions, soil water storage was enhanced at pre-sowing of maize in 2017, but lowered at post-harvest of maize by N application, compared to those from CK treatments. Accordingly, the ET values in 2017 were higher for the $\mathrm{N}$ applications than those for the CK treatment under the RTS and PTS conditions, respectively. Similarly, N application significantly increased WUE by $52.5-89.5 \%$ and $19.0-38.5 \%$ in 2016 , and $42.0-69.2 \%$ and $17.9-26.8 \%$ in 2017 , compared to those for the CK treatment under RTS and PTS conditions, respectively. 
Table 1. ANOVA of tillage with straw incorporation, $\mathrm{N}$ level, and year for soil mineral N storage, root length density (RLD), root weight density (RWD), ratio of root length density (RLDR), ratio of root weight density (RWDR), shoot $\mathrm{N}$ uptake, and grain yield of maize.

\begin{tabular}{|c|c|c|c|c|c|c|c|c|c|}
\hline \multirow{2}{*}{ Source of Variation } & \multicolumn{2}{|c|}{$\begin{array}{c}\text { Soil Mineral N Storage (kg N } \\
\left.\mathrm{ha}^{-1}\right)\end{array}$} & \multicolumn{4}{|c|}{ Root Growth } & \multicolumn{2}{|c|}{ Shoot N Uptake (kg N ha-1) } & \multirow{2}{*}{$\begin{array}{l}\text { Grain Yield } \\
\left(\mathrm{kg} \mathrm{ha}^{-1}\right)\end{array}$} \\
\hline & Pre-Sowing & Post-Harvest & $\begin{array}{c}\text { RLD } \\
\left(\mathrm{cm} \mathrm{cm}^{-3}\right)\end{array}$ & $\begin{array}{c}\mathrm{RWD} \\
\left(\mathrm{mg} \mathrm{cm}^{-3}\right)\end{array}$ & $\begin{array}{l}\text { RLDR } \\
\text { (\%) }\end{array}$ & $\begin{array}{c}\text { RWDR } \\
(\%)\end{array}$ & $\begin{array}{c}\text { Pre-Silking } \\
\text { Shoot N } \\
\text { Uptake (NPS) }\end{array}$ & $\begin{array}{c}\text { Post-Silking } \\
\text { Shoot N Uptake } \\
\text { (NPOS) }\end{array}$ & \\
\hline $\begin{array}{l}\text { Tillage with straw } \\
\text { incorporation (Ts) }\end{array}$ & $228.1^{* * *}$ & $75.9^{* * *}$ & $12.2^{* *}$ & $28.2^{* * *}$ & $16.0^{* * *}$ & $16.3^{* * *}$ & $60.5^{* * *}$ & $0.1^{\mathrm{ns}}$ & $14.9^{* * *}$ \\
\hline $\mathrm{N}$ level $(\mathrm{N})$ & $140.0^{* * *}$ & $182.1^{* * *}$ & $27.4^{* * *}$ & $36.1^{* * *}$ & $24.4^{* * *}$ & $64.0^{* * *}$ & $265.6^{* * *}$ & $59.7^{* * *}$ & $174.3^{* * *}$ \\
\hline Year $(\mathrm{Y})$ & $26.5^{* * *}$ & $273.5^{* * *}$ & $480.8^{* * *}$ & $38.6^{* * *}$ & $514.6^{* * *}$ & $481.7^{* * *}$ & $11.6^{* *}$ & $2.4^{\mathrm{ns}}$ & $96.9^{* * *}$ \\
\hline $\mathrm{Ts} \times \mathrm{N}$ & $36.0 * * *$ & $15.0 * * *$ & $2.1^{\mathrm{ns}}$ & $10.1^{* * *}$ & $14.5^{* * *}$ & $17.2^{* * *}$ & $7.2^{* *}$ & $9.7^{* * *}$ & $13.5^{* * *}$ \\
\hline $\mathrm{Ts} \times \mathrm{Y}$ & $48.3^{* * *}$ & $54.4^{* * *}$ & $5.5 *$ & $0.4^{\mathrm{ns}}$ & $40.3^{* * *}$ & $32.5^{* * *}$ & 19.0 ** & $33.3^{* * *}$ & $0.1^{\mathrm{ns}}$ \\
\hline Ns $\times Y$ & $46.0^{* * *}$ & $28.6^{* * *}$ & $18.3^{* * *}$ & $7.4^{* * *}$ & $5.7 *$ & $20.6^{* * *}$ & $4.0 *$ & $18.1^{* * *}$ & $0.8^{\mathrm{ns}}$ \\
\hline $\mathrm{Ts} \times \mathrm{N} \times \mathrm{Y}$ & $39.0 * * *$ & $0.5^{\mathrm{ns}}$ & $5.0 * *$ & $7.6^{* * *}$ & $6.2 * *$ & $10.7^{* * *}$ & $8.0^{* * *}$ & $3.9 *$ & $0.8^{\mathrm{ns}}$ \\
\hline
\end{tabular}


Table 2. Effect of tillage with straw incorporation and $\mathrm{N}$ treatment on the amount of soil water storage (0-200 cm), field evapotranspiration (ET), and water use efficiency (WUE) of maize.

\begin{tabular}{|c|c|c|c|c|c|c|c|c|c|}
\hline \multicolumn{2}{|c|}{ Treatment } & \multicolumn{2}{|c|}{$\begin{array}{l}\text { Pre-Sowing Soil Water Storage } \\
\text { (mm) }\end{array}$} & \multicolumn{2}{|c|}{$\begin{array}{l}\text { Post-Harvest Soil Water } \\
\text { Storage }(\mathrm{mm})\end{array}$} & \multicolumn{2}{|c|}{ ET (mm) } & \multicolumn{2}{|c|}{ WUE (kg mm $\left.{ }^{-1} \mathrm{ha}^{-1}\right)$} \\
\hline & & RTS & PTS & RTS & PTS & RTS & PTS & RTS & PTS \\
\hline \multirow{4}{*}{2016} & CK & $221 a$ & $214 b$ & $585 \mathrm{~cd}$ & $587 \mathrm{bcd}$ & $448 \mathrm{ab}$ & $438 \mathrm{~cd}$ & $14.3 \mathrm{e}$ & $19.5 d$ \\
\hline & $\mathrm{LN}$ & $220 a$ & $216 b$ & $589 \mathrm{abc}$ & $582 d$ & $442 \mathrm{bc}$ & $445 b$ & $21.8 \mathrm{c}$ & $23.2 \mathrm{bc}$ \\
\hline & $\mathrm{MN}$ & $223 a$ & $212 b$ & $582 d$ & $593 a$ & $452 a$ & $430 \mathrm{e}$ & $24.1 \mathrm{~b}$ & $26.6 \mathrm{a}$ \\
\hline & $\mathrm{HN}$ & $223 a$ & $214 b$ & $590 \mathrm{abc}$ & $592 \mathrm{ab}$ & $444 \mathrm{~b}$ & 434de & $27.4 \mathrm{a}$ & $27.0 \mathrm{a}$ \\
\hline \multirow{6}{*}{2017} & Nmean & $222 \mathrm{~A}$ & 214B & 587A & $588 \mathrm{~A}$ & $446 \mathrm{~A}$ & 437B & 21.9B & $24.1 \mathrm{~A}$ \\
\hline & CK & $266 b$ & $257 \mathrm{~b}$ & $274 a$ & $270 \mathrm{a}$ & $326 \mathrm{~d}$ & $321 \mathrm{e}$ & $22.4 \mathrm{c}$ & $30.2 b$ \\
\hline & $\mathrm{LN}$ & $272 a$ & $257 \mathrm{~b}$ & $259 c$ & $262 b c$ & $346 a$ & $329 d$ & $31.8 \mathrm{~b}$ & $35.6 a$ \\
\hline & $\mathrm{MN}$ & $270 \mathrm{a}$ & $260 b$ & $265 b$ & $255 d$ & $339 b$ & $339 b$ & $37.9 \mathrm{a}$ & $36.9 \mathrm{a}$ \\
\hline & $\mathrm{HN}$ & $269 a$ & $260 \mathrm{~b}$ & $259 \mathrm{~cd}$ & $260 c$ & $345 a$ & $334 c$ & $37.4 \mathrm{a}$ & $38.3 a$ \\
\hline & Nmean & $269 \mathrm{~A}$ & 259B & $264 \mathrm{~A}$ & $262 \mathrm{~A}$ & $339 \mathrm{~A}$ & 330B & $32.4 \mathrm{~B}$ & $35.2 \mathrm{~A}$ \\
\hline \multicolumn{10}{|c|}{ F-value } \\
\hline \multicolumn{2}{|c|}{ Tillage with straw incorporation (Ts) } & \multicolumn{2}{|c|}{$119.4^{* * *}$} & \multicolumn{2}{|c|}{$0.1^{\mathrm{ns}}$} & \multicolumn{2}{|c|}{$98.7^{* * *}$} & \multicolumn{2}{|c|}{$37.2^{* * *}$} \\
\hline \multicolumn{2}{|c|}{ N level $(\mathrm{N})$} & \multicolumn{2}{|c|}{$2.2^{\mathrm{ns}}$} & \multicolumn{2}{|c|}{$10.9^{* * *}$} & \multicolumn{2}{|c|}{$24.3^{* * *}$} & \multicolumn{2}{|c|}{$165.6^{* * *}$} \\
\hline \multicolumn{2}{|c|}{ Year $(Y)$} & \multicolumn{2}{|c|}{$4560.2^{* * *}$} & \multicolumn{2}{|c|}{$169036.5^{* * *}$} & \multicolumn{2}{|c|}{$24021.5^{* * *}$} & \multicolumn{2}{|c|}{$838.2^{* * *}$} \\
\hline \multicolumn{2}{|c|}{ Ts $\times N$} & \multicolumn{2}{|c|}{$0.7^{\mathrm{ns}}$} & \multicolumn{2}{|c|}{$1.0^{\mathrm{ns}}$} & \multicolumn{2}{|c|}{$2.4^{\mathrm{ns}}$} & \multicolumn{2}{|c|}{$13.9^{* * *}$} \\
\hline \multicolumn{2}{|c|}{ Ts $\times Y$} & \multicolumn{2}{|c|}{$24.2^{* * *}$} & \multicolumn{2}{|c|}{$5.9 *$} & \multicolumn{2}{|c|}{$4.0^{\mathrm{ns}}$} & \multicolumn{2}{|c|}{$2.2^{\mathrm{ns}}$} \\
\hline \multirow{2}{*}{\multicolumn{2}{|c|}{$\begin{array}{c}N \times Y \\
\text { Ts } \times N \times Y\end{array}$}} & & & & & & & & \\
\hline & & & & & & & & & \\
\hline
\end{tabular}

RTS, rotary tillage with straw incorporation; PTS, plow tillage with straw incorporation. CK, LN, MN, and HN indicate $0,112,187$, and 262 kg N ha ${ }^{-1}$ applied, respectively. Different uppercase and lowercase letters indicate comparisons with significant difference $(p<0.05)$ between tillage with straw incorporation regimes and $\mathrm{N}$ treatment, respectively; ${ }^{\text {ns }}$, no significant difference; ${ }^{*}$ and ${ }^{* * *}$ indicate significant differences among treatments at $p<0.05$ and $p<0.01$, respectively. 


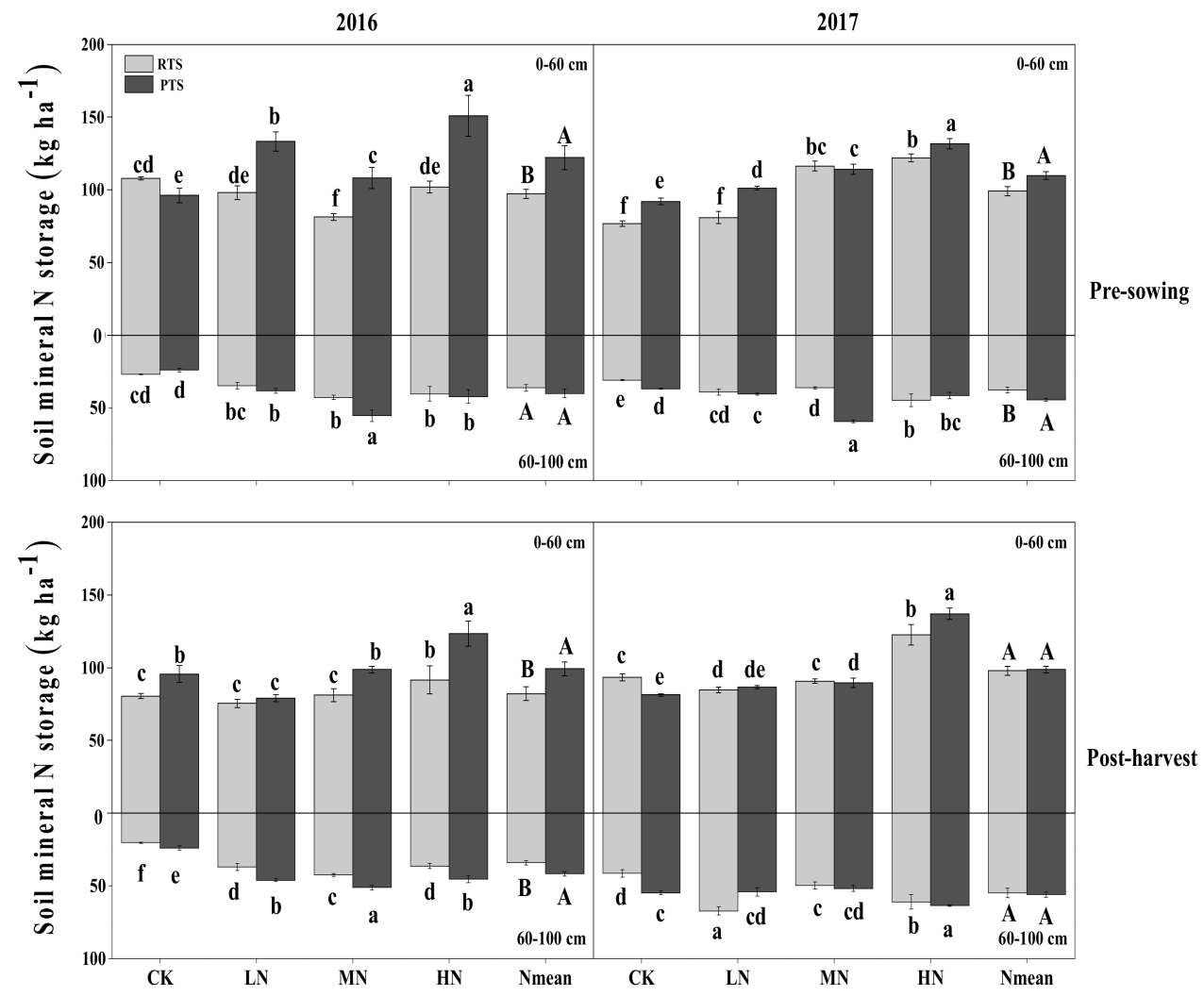

Figure 2. Response of soil mineral $\mathrm{N}$ storage to tillage with straw incorporation and $\mathrm{N}$ treatment in 2016-2017. RTS, rotary tillage with straw incorporation; PTS, plow tillage with straw incorporation. CK, LN, MN, and HN indicate $0,112,187$, and $262 \mathrm{~kg} \mathrm{~N} \mathrm{ha}^{-1}$ applied, respectively. Nmean, the mean values of different N. Different uppercase and lowercase letters indicate significant differences for soil mineral $\mathrm{N}$ storage between tillage with straw incorporation regimes and $\mathrm{N}$ levels for $p<0.05$ level, respectively.

\subsection{Root Traits}

According to the ANOVA results in Table 1 , in addition to $\mathrm{Ts} \times \mathrm{N}$ for root length density (RLD) and Ts $\times Y$ for root weight density (RWD), significant effects were observed for maize RLD, RWD, and the ratios of root length density (RLDR) and root weight density (RWDR) for Ts, N, and Y, as well as the interactions between them. As for maize RLD, there was a declining trend across the $0-40 \mathrm{~cm}$ soil layer for all treatments in both years; however, no obvious changes were found from the results beyond the $40 \mathrm{~cm}$ soil layer (Figure 3). Moreover, larger variations between $\mathrm{N}$ level treatments were observed in the $0-10 \mathrm{~cm}$ and $10-20 \mathrm{~cm}$ soil layers under RTS condition compared with the results from PTS. Compared with CK, treatments with $\mathrm{N}$ applications improved RLD in the $0-10 \mathrm{~cm}$ soil layer by 2.1-3.4-fold and 1.8-2.1-fold in 2016, 1.2-1.6-fold and 1.1-1.4-fold in 2017 under RTS and PTS practices, respectively. Similar trends regarding maize RWD in the $0-60 \mathrm{~cm}$ soil layer and variations between N level treatments were seen in both growth seasons as well (Figure 4). In the $0-10 \mathrm{~cm}$ sampling layer, in 2016, 1.5-4.8-fold and 1.2-3.1-fold; and in 2017, 1.2-2.3-fold and 1.2-1.5-fold higher RWD results were observed for the treatments with N, compared with those from CK. Overall, lower RLD and RWD results were obtained in 2016 (with an average of $1.2-2.2 \mathrm{~cm} \mathrm{~cm}^{-3}$ and $0.6-1.3 \mathrm{mg} \mathrm{cm}^{-3}$ ) than in 2017 (with an average of $2.3-3.2 \mathrm{~cm} \mathrm{~cm}^{-3}$ and $0.8-1.4 \mathrm{mg} \mathrm{cm}^{-3}$ ). 


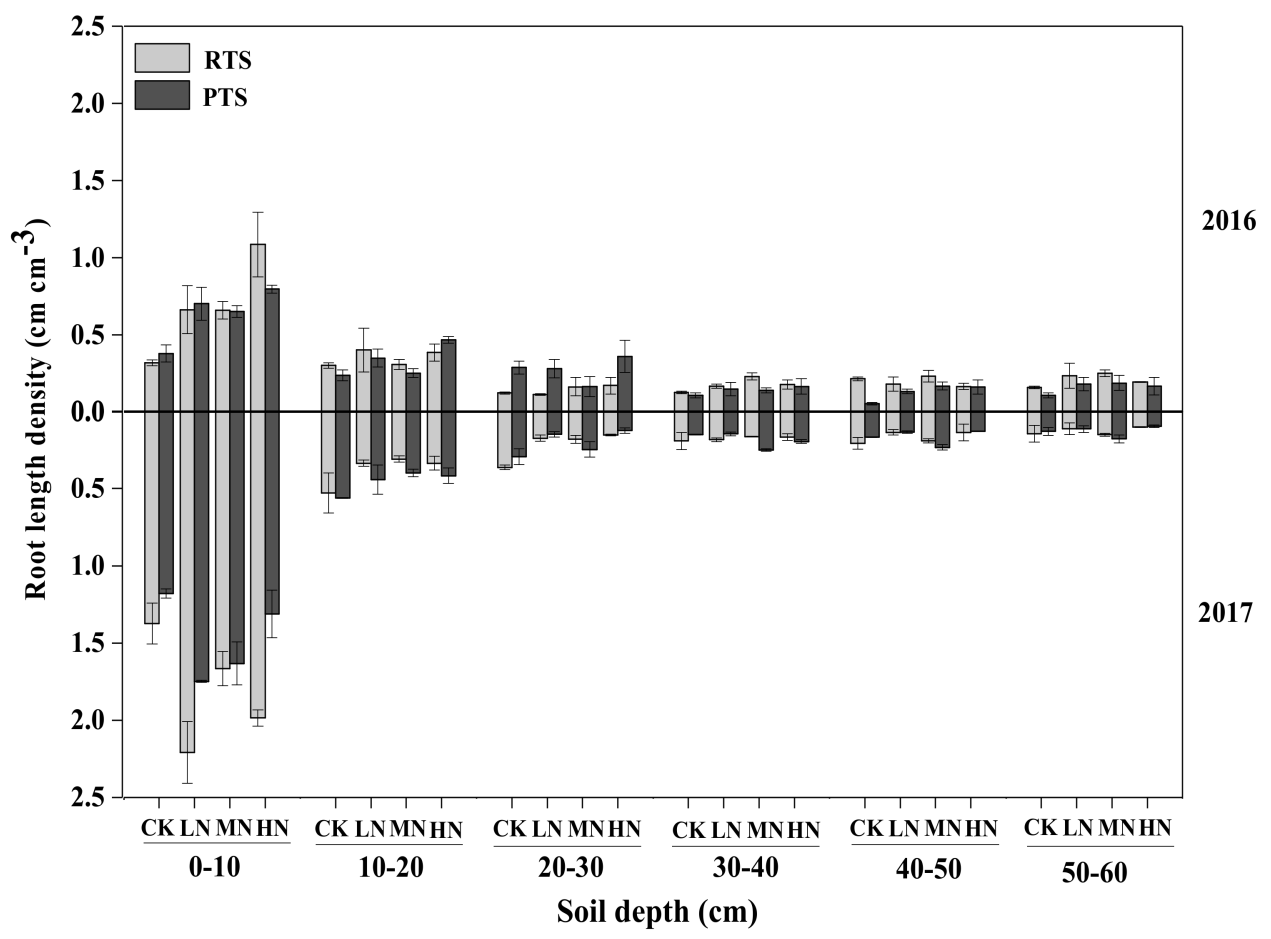

Figure 3. Response of root length density to tillage with straw incorporation and $\mathrm{N}$ treatment in 2016-2017. RTS, rotary tillage with straw incorporation; PTS, plow tillage with straw incorporation. CK, LN, MN, and HN indicate $0,112,187$, and $262 \mathrm{~kg} \mathrm{~N} \mathrm{ha}^{-1}$ applied, respectively.

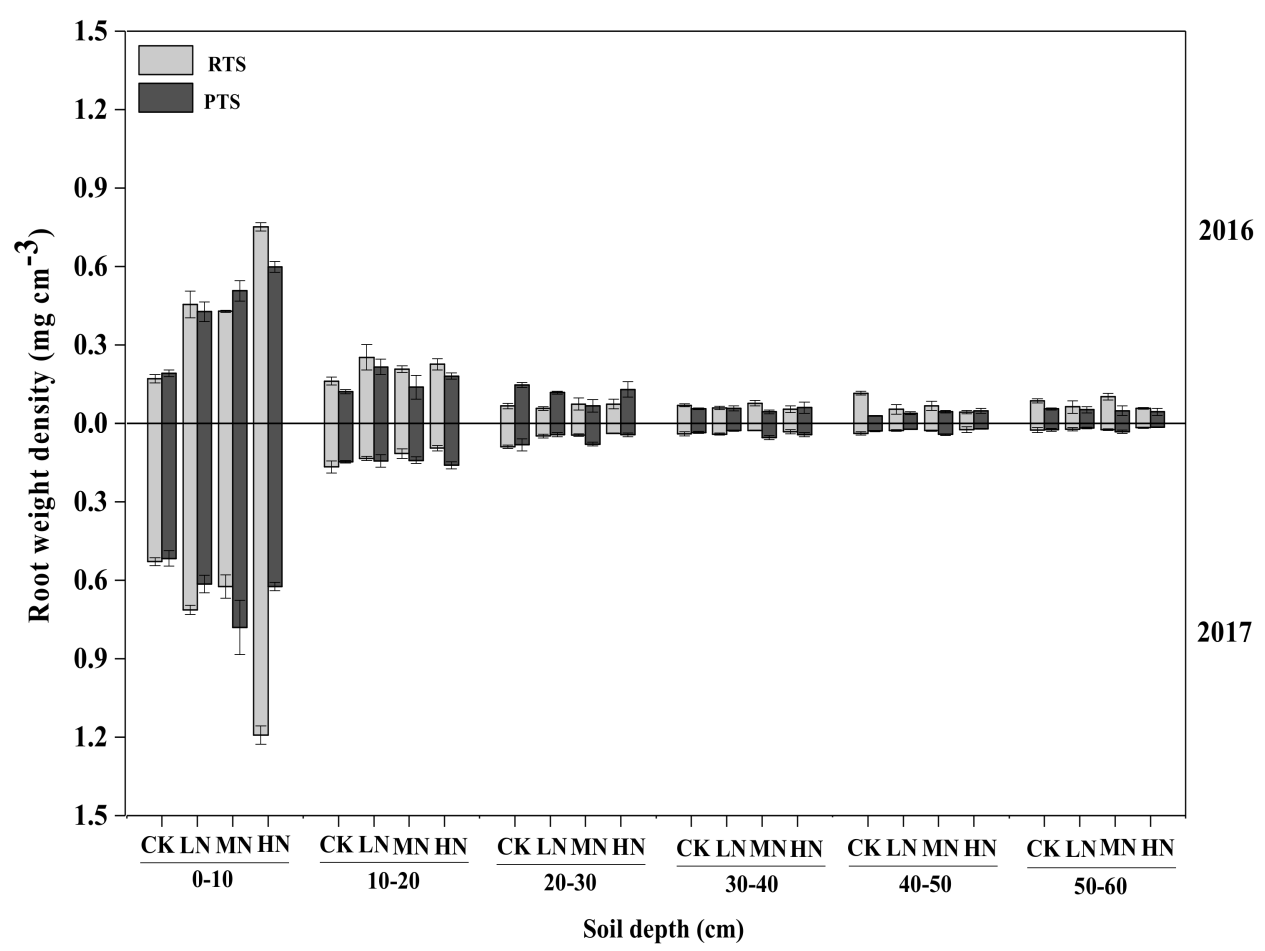

Figure 4. Response of root weight density to tillage with straw incorporation and $\mathrm{N}$ treatment in 2016-2017. RTS, rotary tillage with straw incorporation; PTS, plow tillage with straw incorporation. CK, LN, MN, and HN indicate $0,112,187$, and $262 \mathrm{~kg} \mathrm{~N} \mathrm{ha}^{-1}$ applied, respectively. 
RLDR and RWDR under HN treatment were found with high values in the $0-30 \mathrm{~cm}$ soil layer and low values in the 30-60 $\mathrm{cm}$ soil layer, and the trends were reversed for root distribution in the 0-30 cm and 30-60 cm soil layers in CK, LN, and MN treatments (Figure 5). In 2016, RTS managements increased the RLDR and RWDR in the $30-60 \mathrm{~cm}$ soil layer by $31.4 \%$ and $27.9 \%$, respectively, compared to those from PTS. However, similar results were observed between RTS and PTS according to the Nmean. On average, RLDR and RWDR in the $30-60 \mathrm{~cm}$ soil layer fluctuated by $23.2-40.3 \%$ and $12.0-33.0 \%$ in 2016, and $13.7-22.5 \%$ and $5.2-11.6 \%$ in 2017 under RTS and PTS treatments, respectively.
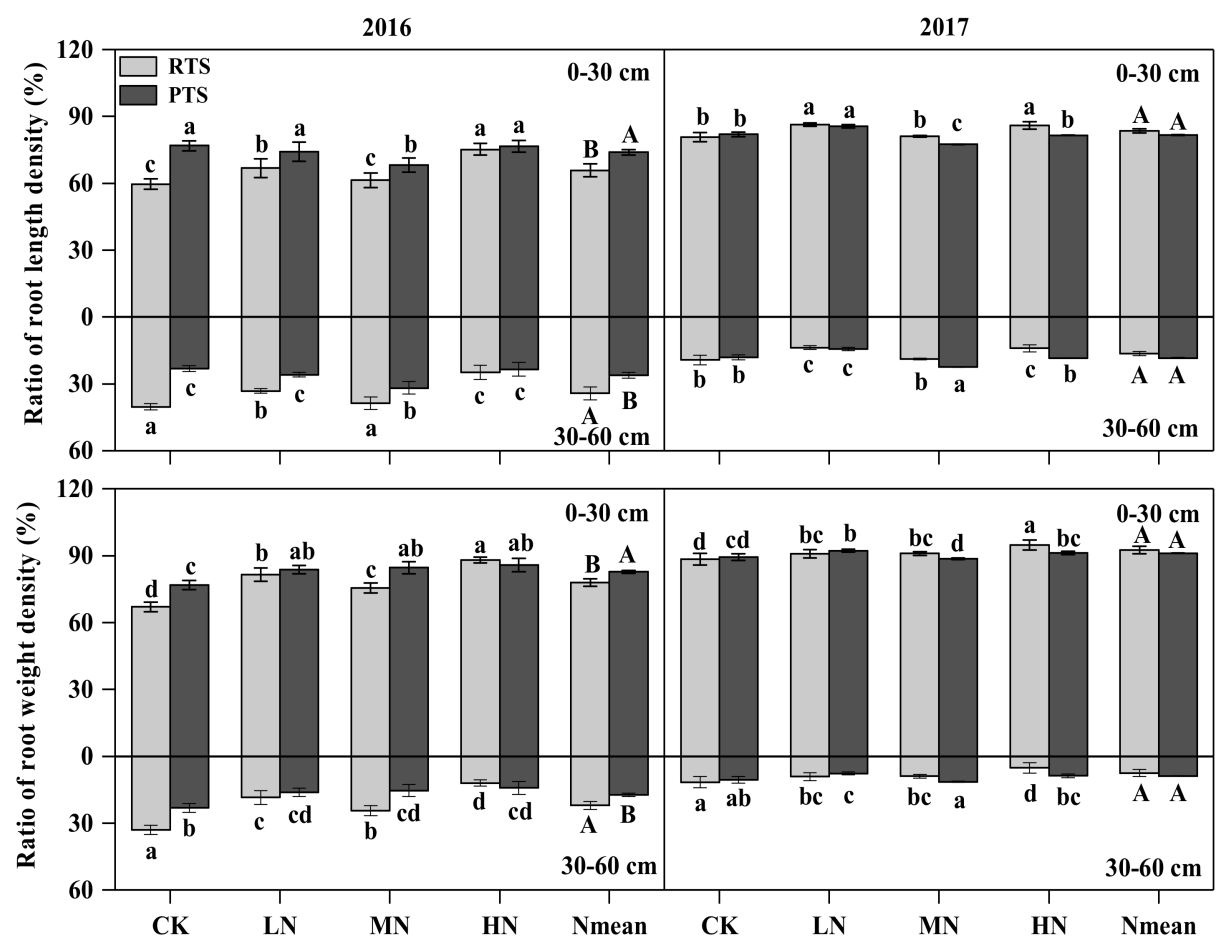

Figure 5. Response of ratios of root length density and root weight density to tillage with straw incorporation and N treatment in 2016-2017. RTS, rotary tillage with straw incorporation; PTS, plow tillage with straw incorporation. CK, LN, MN, and HN indicate $0,112,187$, and $262 \mathrm{~kg} \mathrm{~N} \mathrm{ha}^{-1}$ applied, respectively. Nmean, the mean values of different $\mathrm{N}$. Different uppercase and lowercase letters indicate significant differences for ratios of root length density and root weight density between tillage with straw incorporation and $\mathrm{N}$ treatment for $p<0.05$ level, respectively.

\subsection{Shoot N Uptake Pre- and Post-Silking}

With respect to shoot $\mathrm{N}$ uptake, in addition to the Ts and $\mathrm{Y}$ at $\mathrm{N}$ uptake post-silking (NPOS), significant effects on shoot $\mathrm{N}$ accumulation at pre-silking and post-silking stages were observed for $\mathrm{Ts}$, $\mathrm{N}$, and $\mathrm{Y}$, as well as the interactions between them (Table 1). Significantly higher pre-silking shoot $\mathrm{N}$ uptake (NPS) was obtained from treatments with N application under RTS and PTS conditions, compared to those for CK in 2016 and 2017 (Figure 6). During this period, shoot N uptake was enhanced as the N supplement increased. Treatments from PTS were found with higher NPS values than those from RTS. With respect to NPOS, there was no consistent impact found between N levels or tillage with straw incorporation regimes. In 2016, HN and MN treatments significantly improved NPOS under RTS and PTS, compared to CK. Comparing RTS with PTS, opposite effects were produced regarding NPOS between 2016 and 2017. 


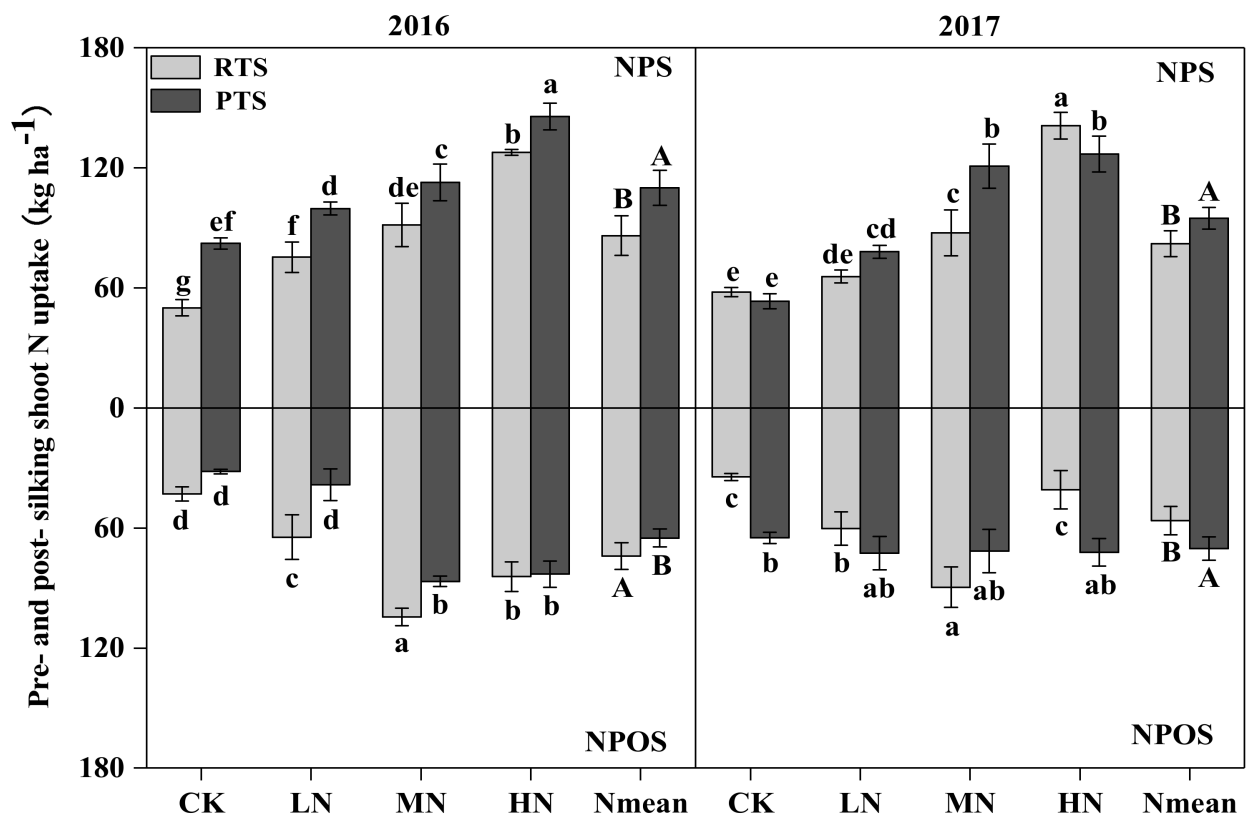

Figure 6. Response of shoot $\mathrm{N}$ uptake at maize pre-silking and post-silking to tillage with straw incorporation and N level management in 2016-2017. NPS, shoot N uptake at pre-silking of maize; NPOS, shoot N uptake post-silking of maize; RTS, rotary tillage with straw incorporation; PTS, plow tillage with straw incorporation. CK, LN, MN, and HN indicate $0,112,187$, and $262 \mathrm{~kg} \mathrm{~N} \mathrm{ha}^{-1}$ applied, respectively. Nmean, the mean values of different $\mathrm{N}$. Different uppercase and lowercase letters indicate significant differences for shoot $\mathrm{N}$ uptake before and after maize silking between tillage with straw incorporation and $\mathrm{N}$ treatment for $p<0.05$ level, respectively.

\subsection{Grain Yield}

Significant effects on maize grain yield were observed for factors $\mathrm{Ts}, \mathrm{N}$, and $\mathrm{Y}$, as well as for the Ts $\times \mathrm{N}$ interaction (Table 1). Mean grain yield under PTS were $6.7 \%$ and $6.0 \%$ higher than those under RTS in 2016 and 2017 (Figure 7). Compared to the CK treatment, grain yields were significantly enhanced by $\mathrm{N}$ application with increases of $50.4-89.7 \%$ and $21.0-37.7 \%$ in 2016 , and $48.4-73.9 \%$ and 19.8-30.7\% in 2017, under the RTS and PTS systems, respectively. Except for RTS in 2016, there was no significant improvement in grain yield with increased $\mathrm{N}$ supplementation while the amount of $\mathrm{N}$ applied was over the MN level. On average, maize grain yield under both the RTS and PTS systems fluctuated: $6407-12154 \mathrm{~kg} \mathrm{ha}^{-1}$ in 2016, and 7406-12875 $\mathrm{kg} \mathrm{ha}^{-1}$ in 2017. 


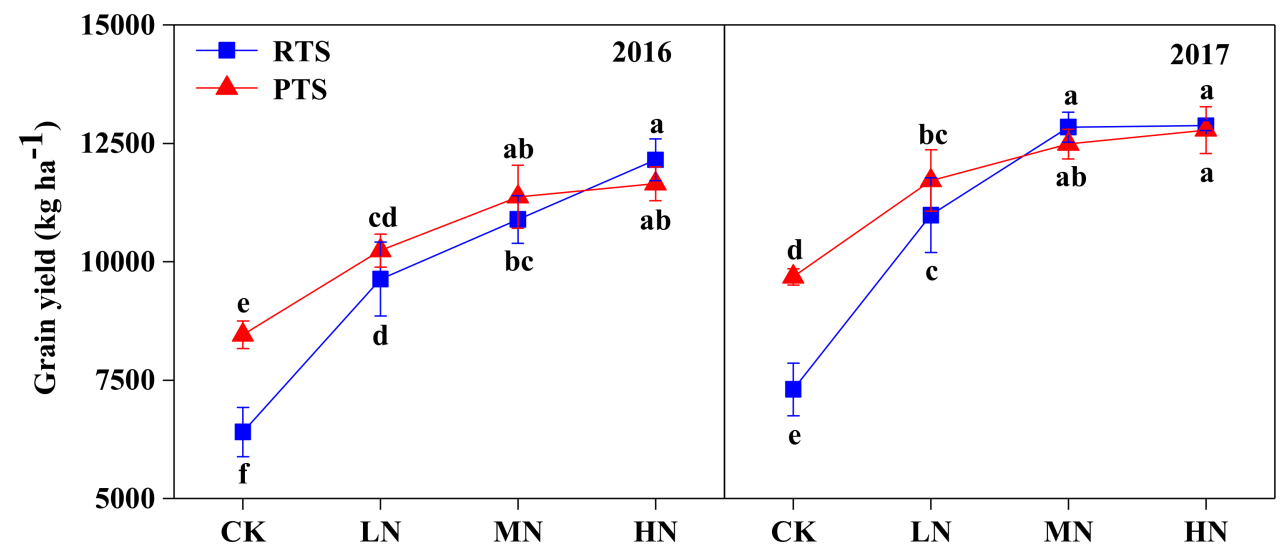

Figure 7. Response of grain yield to tillage with straw incorporation and N treatment in 2016-2017. RTS, rotary tillage with straw incorporation; PTS, plow tillage with straw incorporation. CK, LN, $\mathrm{MN}$, and $\mathrm{HN}$ indicate $0,112,187$, and $262 \mathrm{~kg} \mathrm{~N}$ ha $^{-1}$ applied, respectively. Different lowercase letters indicate significant differences for grain yield between tillage with straw incorporation and $\mathrm{N}$ treatment for $p<0.05$ level, respectively.

3.5. Direct and Indirect Impacts of Tillage with Straw Incorporation and N Rate Induced Factors on Maize Grain Yield

A structural equation model (SEM) was used to analyze the direct and indirect effects of soil mineral $\mathrm{N}$ storage, field evapotranspiration (ET), as well as the root traits and $\mathrm{N}$ uptake of maize on the grain yield (Figure 8). The total variation in maize grain yield was shown to be $87 \%$ by SEM analysis $(p=0.755, \mathrm{CFI}=1.000, \mathrm{GFI}=0.993$, RMSEA $=0.000)$. Among these drivers, shoot $\mathrm{N}$ uptake at pre-silking (NPS) and post-silking (NPOS) of maize directly contributed to the maize grain yield. Soil mineral N storage and ET were involved with the maize grain yield by mediating root traits, which further affected NPS and NPOS. For instance, RWD and RWDR were found to have a positive effect on NPS and NPOS, respectively; RLD and RLDR were observed to have a negative effect on NPS and NPOS, respectively. Moreover, it is worth noting that tillage with straw incorporation and $\mathrm{N}$ level management influenced maize grain yield indirectly through soil mineral $\mathrm{N}$ storage at both pre-sowing and post-harvest. 


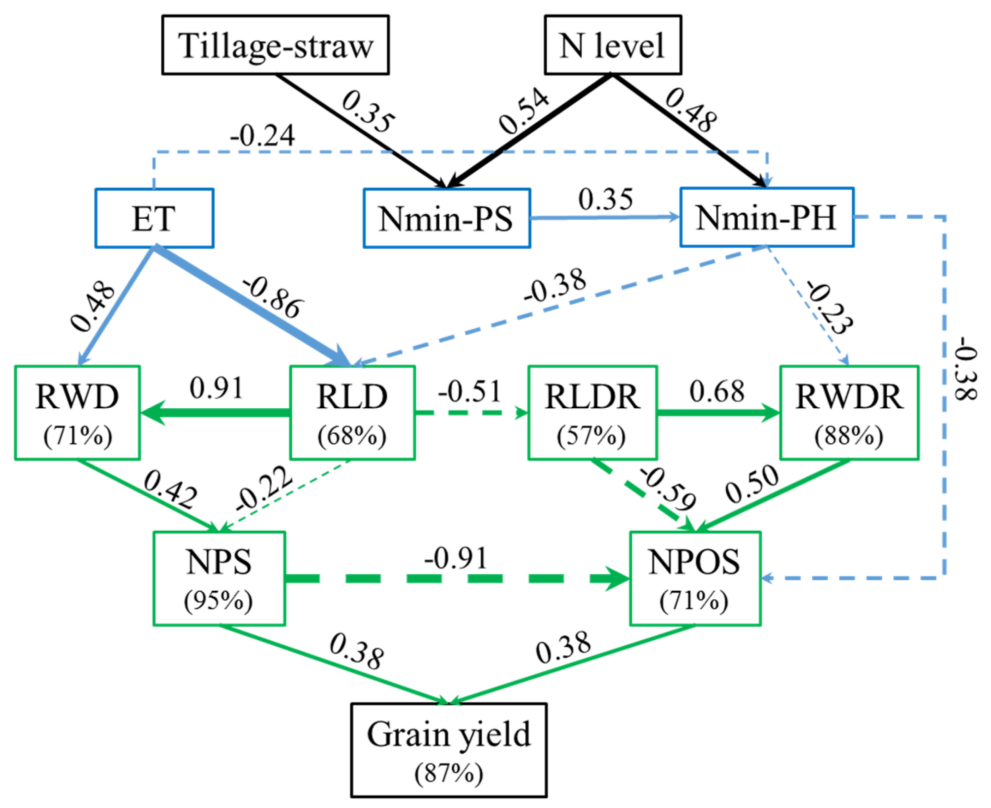

Figure 8. Structural equation model showing the potential mechanism of tillage with straw incorporation and $\mathrm{N}$ rate management related to the maize yield over two years $\left(\chi^{2}=2.644, \mathrm{df}=5, p=0.755, \mathrm{CFI}\right.$ $=1.000, \mathrm{GFI}=0.993, \mathrm{RMSEA}=0.000)$. Continuous and dashed arrows indicate positive $(p<0.05)$ and negative $(p<0.05)$ relationships, respectively. Numbers (standardized path coefficients) on the arrows that follow the included variables show the explained percentage of variance by the predictors. The width of arrow indicates the strength of the standardized path coefficient. Field evapotranspiration (ET), soil mineral $\mathrm{N}$ storage in the $0-60 \mathrm{~cm}$ soil layer at pre-sowing (Nmin-PS), soil mineral N storage in the 0-60 cm soil layer at post-harvest (Nmin-PH), root length density (RLD) in the 0-60 cm soil layer, root weight density (RWD) in the $0-60 \mathrm{~cm}$ soil layer, ratio of root length density (RLDR) in the 0-30 cm soil layer, ratio of root weight density proportion (RWDR) in the $0-30 \mathrm{~cm}$ soil layer, pre-silking shoot $\mathrm{N}$ uptake (NPS), and post-silking shoot $\mathrm{N}$ uptake (NPOS).

\section{Discussion}

\subsection{Soil Water and Mineral N Storage}

The amount and spatial distribution of rainfall during crop growth period will affect the availability of soil water and nutrients. Soil water retention is considered one of the main benefits of straw incorporation in terms of increasing crop grain yield in drought-prone areas where crop production is limited by soil moisture [5]. Our results reported a higher soil water storage at pre-sowing (SW-PS) for the RTS system in 2016 and 2017, compared to the PTS system (Table 2). This indicates that RTS reduced soil evaporation during the non-growing season, which is in agreement with the higher levels of soil water retention achieved by rotary tillage over plow tillage [11]. However, there was no significant difference of soil water storage at post-harvest (SW-PH) between RTS and PTS (Table 2) suggesting that a higher level of soil water retention was observed under the PTS system than under the RTS system during the growing season. Moreover, the ET values under the RTS system in this study were higher than under the PTS system in both 2016 and 2017 (Table 2). These results might be explained by the fact that PTS reduced soil bulk density and increased soil porosity and rainfall interception, accounting for the enhanced capacity for soil water storage $[13,15,16,40]$.

Incorporating straw into the soil not only increased the capacity of the soil to store water, but also affected soil mineral $\mathrm{N}$ dynamics and utilization [41]. However, soil mineral $\mathrm{N}$ (Nmin) profit significantly differed between the different tillages with straw incorporation management approaches, due to differences in crop $\mathrm{N}$ uptake and straw decomposition as well as nitrate leaching $[18,42,43]$. In this study, we calculated Nmin consumption between the pre-sowing stage in 2016 and the post-harvest 
stage in 2017, and a clear increase in Nmin consumption under PTS was observed (the average Nmin decreased by $21 \mathrm{~kg} \mathrm{~N} \mathrm{ha}^{-1}$ ), relative to the RTS system (the average Nmin increased by $20 \mathrm{~kg} \mathrm{~N} \mathrm{ha}^{-1}$ ) (Figure 2). Meanwhile, the shoot $\mathrm{N}$ uptake was only $31 \mathrm{~kg} \mathrm{~N} \mathrm{ha}^{-1}$ higher under PTS than for the RTS system in the two growing seasons (Figure 6). Further analysis of these data revealed that the amount of unaccounted N for PTS was higher than for RTS (unpublished data). This finding could be likely explained by the following reasons: (i) Compared to PTS, the straw better mixed with the soil at shallower depths under RTS, which made straw decomposition more efficient as a result of the aerobic soil environment. Thus, straw-derived N could be converted into the Nmin pool within a relatively short time [42]; (ii) A portion of the applied $\mathrm{N}$ might leach down below a soil depth of $100 \mathrm{~cm}$ in PTS because of better water infiltration to the subsoil layer during intensive rainfall in the growing seasons [43].

\subsection{Root Distribution and N Uptake}

Root systems, which are extensively affected by precipitation, tillage with straw incorporation management, and $\mathrm{N}$ levels, contribute greatly to the maintenance of the supply of water and mineral nutrients to the crops [14,21]. In this study, the RLD and RWD in the 0-60 cm soil layer were significantly increased in 2017 compared to 2016, which was mostly owing to the lower rainfall in May 2017, when the moderate soil water deficit stimulated the growth of the maize root systems (Figures 3 and 4). Previous studies indicated that tillage with straw incorporation practices influenced the soil structure, which could affect root growth and distribution [44]. Our findings show that the RLD and RWD in the $0-10 \mathrm{~cm}$ soil layer in 2016-2017 and in the 40-60 cm soil layer in 2016, as well as the ratios of root in the 30-60 cm soil layer in 2016 under RTS, were greater than under PTS (Figures 3-5), which is in accordance with the results of Ren et al. [45]. In addition, the RLD and RWD in the 20-30 cm soil layer under PTS were markedly higher than those under RTS in our study (Figures 3 and 4). Deep tillage might break up dense soil layers, thus improving soil ventilation and rainfall interception, which is beneficial for better root growth and distribution in the plow layer, enhancing soil water and nutrients acquisition [46]. Furthermore, root systems can perceive changes in soil nutrients, thus coordinating the root morphological changes, which can be significantly regulated by fertilizer application [34]. We found that the relevant higher RLD values in the 0-30 cm soil layer among the $\mathrm{N}$ treatments were obtained for HN in 2016 and LN in 2017, respectively. However, for the subsoil layer, the RLD of MN was higher than for the other $\mathrm{N}$ levels (Figure 3). Furthermore, the RLDR in the 30-60 cm soil layer under MN was higher than for the other $\mathrm{N}$ levels (Figure 5), which indicates that properly reducing $\mathrm{N}$ application levels promotes root growth in the deep soil layers [21].

Mean shoot N uptake pre-silking under PTS was enhanced by $17.6 \%$ compared to those under RTS; whereas, shoot $\mathrm{N}$ uptake post-silking under the two tillage with straw incorporation systems were similar (Figure 6). According to Guan et al. [18], under plow tillage, reducing soil compaction resistance might facilitate roots to uptake soil water and mineral $\mathrm{N}$ more than under shallow tillage. Otherwise, the straw was better mixed with the soil, at shallower levels under RTS, which decreased soil mineral $\mathrm{N}$ due to microbial immobilization, thus intensifying the competition for soil mineral $\mathrm{N}$ between microorganisms and crops in the early growth stage [9]. Root growth made the crops more competitive for soil mineral $\mathrm{N}$ compared to microbes [8]. Furthermore, microbial biomass $\mathrm{N}$ might be released in the latter growth, and so, improved crop $\mathrm{N}$ acquisition and reduced the $\mathrm{N}$ accumulation gap with PTS [8]. Notably, shoot $\mathrm{N}$ uptake was improved as $\mathrm{N}$ application increased; however, there was no significant improvement when $\mathrm{N}$ was applied over $187 \mathrm{~kg} \mathrm{~N} \mathrm{ha}^{-1}$ in 2017 (Figure 6). In the drought season, sufficient $\mathrm{N}$ application could stop the soil $\mathrm{N}$ being a limiting factor, thus soil water content might determine crop $\mathrm{N}$ uptake [21].

\subsection{Grain Yield and Water Use Efficiency}

In our study, PTS significantly increased maize grain yield over the two growing seasons, compared with RTS (Figure 7). This finding was in accordance with the results of Guan et al. [18] and Mu 
et al. [13]. It was most probably associated with better water and $\mathrm{N}$ availability under PTS, which might have helped better crop growth and $\mathrm{N}$ uptake in the growing seasons, contributing to a higher maize grain yield [11,46]. Similar responses were found from a cool Atlantic climate in central Ireland, which reported that PTS also significantly enhanced winter wheat grain yield in a three years field research [47]. Specifically, maize grain yields were enhanced in response to increasing $\mathrm{N}$ application; however, the grain yield did not show further significant improvements when the amount of $\mathrm{N}$ applied was over $187 \mathrm{~kg} \mathrm{~N} \mathrm{ha}^{-1}$ (except for RTS in 2016). The results indicate that extra $\mathrm{N}$ applications (above the aforementioned level) do not promote grain yield, and even probably have a negative effect in rainfed conditions [21]. Similar responses were found from the Northeast China Plain, which reported that the highest grain yield of maize was obtained with an $\mathrm{N}$ application rate of around $160 \mathrm{~kg} \mathrm{~N} \mathrm{ha}^{-1}$ in similar rainfed condition [48]. Interestingly, the highest and lowest grain yields were found with $\mathrm{HN}$ and CK under RTS (Figure 7). This may be because of mineral $\mathrm{N}$ being unavailable as a result of the intense competition between microorganisms and plants under CK treatments [9]. Conversely, a sufficient $\mathrm{N}$ supply could alleviate the competition pressure and stimulate root growth due to the need to acquire more soil water and mineral $\mathrm{N}$, which were beneficial to the high grain yield [8].

PTS remarkably increased WUE compared to RTS, on account of improving grain yield and reducing ET (Table 2). Similar results also showed that plow tillage reduced soil bulk density and penetration resistance and improved grain yield and water use efficiency [11]. Moreover, deep tillage can break the subsoil compacted layers and promote root growth, thus enhancing crop production $[13,17]$. In addition, in the current study, $\mathrm{N}$ application treatments presented a significantly higher WUE than those under CK (Table 2); however, WUE did not show further significant improvements when the amount of N applied was over MN (except for RTS in 2016), and thus grain yield failed to increase.

\subsection{The Potential Mechanism of Maize Grain Yield Response to Tillage with Straw Incorporation Management and $N$ Levels}

The sustainability of obtaining a higher crop grain yield is mainly attributed to improvements in soil water retention and soil nutrient supply $[16,48]$. In particular, SEM indicated that the potential of soil water retention and the condition of Nmin were regulated by tillage with straw incorporation management and $\mathrm{N}$ levels, which can indirectly affect maize grain yield by mediating root distribution and plant $\mathrm{N}$ uptake (Figure 8). Furthermore, the potential mechanisms involved in plant $\mathrm{N}$ uptake were the difference between the vegetative and reproductive phases. In the early growing seasons, RLD was the key indicator providing information on the capacity of the soil to supply water and nutrients [27] and was significantly negatively correlated with ET and Nmin-PH (Figure 8). Moreover, RLD was positively correlated with RWD, but NPS exhibited a converse relationship with RLD (-) and RWD (+). Generally, root growth and N uptake are synchronized with shoot development and, thus, there would be competition between root and shoot sinks when soil water and $\mathrm{N}$ resources are limited under drought conditions or low $\mathrm{N}$ input [28,31]. For example, longer axile roots and steeper root angles under low $\mathrm{N}$ stress resulted in an increase in efficiently forage $\mathrm{N}$ in the soil [25,34]. As shown in Figure 8, RLDP had positive effects on RWDP, while NPOS exhibited a converse relationship with RLDP (-) and RWDP (+). Meanwhile, Nmin-PH was negatively correlated with RWDP and NPOS. The results indicate that RLDP in the deep soil layers played a pivotal role in the absorption of the available $\mathrm{N}$ in the soil, which was conducive to delaying root senescence and improved plant $\mathrm{N}$ uptake during the latter growing seasons [21,49]. Ultimately, NPS and NPOS directly contributed to the variation in maize grain yield, though NPS had a significantly negative correlation with NPOS (Figure 8). Soil available $\mathrm{N}$ was taken up by the root systems to meet the accelerated growth of the shoots during vegetative growth, and the accumulated $\mathrm{N}$ in the vegetative parts of the crop was remobilized and translocated to the maize grain after flowering [31]. In parallel, it would be necessary to take into account that $\mathrm{N}$ remobilization could decrease the total green leaf area after silking, which would reduce the duration of photosynthesis and have a negative effect on $\mathrm{N}$ uptake in the post-silking stages [50]. 


\section{Conclusions}

Examining rotary and plow tillage with straw incorporation combine with $\mathrm{N}$ levels on maize root distribution and $\mathrm{N}$ uptake in northeast China showed a clear consistency of the importance of straw incorporation on steady increases in crop production. These results provide useful information when dealing with important issues of straw use and soil degradation in China. However, straw decomposes slowly in the field and the released nutrients cannot satisfy the rapid nutrient requirements necessary for crop growth. Hence, balancing nitrogen fertilizer consumption and straw incorporation practices is imperative and the foundation of sustainable agricultural development. Long-term trials are needed to understand the effects of straw incorporation practices in different regions and cropping systems.

Author Contributions: Designed and performed most of the experiments, analyzed the data and wrote the manuscript, P.S., H.Q., and Y.J.; helped with the data collection and analysis, editing of the manuscript as well, H.L., Z.W., N.M., G.M., Y.S. (Yue Sun), Y.W., Y.S. (Yehan Su), Z.M., and P.T. All authors have read and agreed to the published version of the manuscript.

Funding: This research was funded by the Special Fund for Agro-scientific Research in the Public Interest (201503116); The National Key Research and Development Program of China (2016YFD0300801, 2016YFD0300103).

Conflicts of Interest: The authors declare no conflict of interest. The funders had no role in the design of the study; in the collection, analyses, or interpretation of data; in the writing of the manuscript, or in the decision to publish the results.

\section{References}

1. Wang, S.; Zhang, C. Spatial and temporal distribution of air pollutant emissions from open burning of crop residues in China. Sci. Online 2008, 3, 329-333.

2. Li, H.; Cao, Y.; Wang, X.M.; Ge, X.; Li, B.Q.; Jin, C.Q. Evaluation on the production of food crop straw in China from 2006 to 2014. BioEnergy Res. 2017, 10, 949-957. [CrossRef]

3. Zhang, J.; Hang, X.; Lamine, S.M.; Jiang, Y.; Afreh, D.; Qian, H.; Feng, X.; Zheng, C.; Deng, A.; Song, Z.; et al. Interactive effects of straw incorporation and tillage on crop yield and greenhouse gas emissions in double rice cropping system. Agric. Ecosyst. Environ. 2017, 250, 37-43. [CrossRef]

4. $\mathrm{Qu}, \mathrm{C} . ; \mathrm{Li}, \mathrm{B} . ; \mathrm{Wu}, \mathrm{H}$; Giesy, J.P. Controlling air pollution from straw burning in China calls for efficient recycling. Environ. Sci. Technol. 2012, 46, 7934-7936. [CrossRef]

5. Turmel, M.S.; Speratti, A.; Baudron, F.; Verhulst, N.; Govaerts, B. Crop residue management and soil health: A systems analysis. Agric. Syst. 2015, 134, 6-16. [CrossRef]

6. Li, H.; Dai, M.W.; Dai, S.L.; Dong, X.J. Current status and environment impact of direct straw return in China's cropland-A review. Ecotox. Environ. Saf. 2018, 159, 293-300. [CrossRef]

7. Yin, H.J.; Zhao, W.Q.; Li, T.; Cheng, X.Y.; Liu, Q. Balancing straw returning and chemical fertilizers in China: Role of straw nutrient resources. Renew. Sustain. Energy Rev. 2018, 81, 2695-2702. [CrossRef]

8. Kuzyakov, Y.; Xu, X.L. Competition between roots and microorganisms for nitrogen: Mechanisms and ecological relevance. New Phytol. 2013, 198, 656-669. [CrossRef]

9. Li, X.G.; Jia, B.; Lv, J.T.; Ma, Q.J.; Kuzyakov, Y.; Li, F.M. Nitrogen fertilization decreases the decomposition of soil organic matter and plant residues in planted soils. Soil Biol. Biochem. 2017, 112, 47-55. [CrossRef]

10. Hou, P.; Gao, Q.; Xie, R.Z.; Li, S.K.; Meng, Q.F.; Kirkby, E.A.; Römheld, V.; Müller, T.; Zhang, F.S.; Cui, Z.L.; et al. Grain yields in relation to $\mathrm{N}$ requirement: Optimizing nitrogen management for spring maize grown in China. Field Crop. Res. 2012, 129, 1-6. [CrossRef]

11. Guan, D.; Zhang, Y.; Al-Kaisi, M.M.; Wang, Q.; Zhang, M.; Li, Z. Tillage practices effect on root distribution and water use efficiency of winter wheat under rain-fed condition in the North China Plain. Soil Tillage Res. 2015, 146, 286-295. [CrossRef]

12. Bolaños, J.; Edmeades, G.O. The importance of the anthesis-silking interval in breeding for drought tolerance in tropical maize. Field Crop. Res. 1996, 48, 65-80. [CrossRef]

13. Mu, X.Y.; Zhao, Y.L.; Liu, K.; Ji, B.Y.; Guo, H.B.; Xue, Z.W.; Li, C.H. Responses of soil properties, root growth and crop yield to tillage and crop residue management in a wheat-maize cropping system on the North China Plain. Eur. J. Agron. 2016, 78, 32-43. [CrossRef] 
14. Mosaddeghi, M.R.; Mahboubi, A.A.; Safadoust, A. Short-term effects of tillage and manure on some soil physical properties and maize root growth in a sandy loam soil in western Iran. Soil Tillage Res. 2009, 104, 173-179. [CrossRef]

15. Laddha, K.C.; Totawat, K.L. Effects of deep tillage under rainfed agriculture on production of sorghum (Sorghum biocolor L. Moench) intercropped with green gram (Vigna radiata L. Wilczek) in western India. Soil Tillage Res. 1997, 43, 241-250. [CrossRef]

16. Berhe, F.T.; Fanta, A.; Alamirew, T.; Melesse, A.M. The effect of tillage practices on grain yield and water use efficiency. Catena 2012, 100, 128-138. [CrossRef]

17. Cai, H.G.; Ma, W.; Zhang, X.Z.; Ping, J.Q.; Yan, X.G.; Liu, J.Z.; Yuan, J.C.; Wang, L.C.; Ren, J. Effect of subsoil tillage depth on nutrient accumulation, root distribution, and grain yield in spring maize. Crop. J. 2014, 2, 297-307. [CrossRef]

18. Guan, D.H.; Al-Kaisi, M.M.; Zhang, Y.S.; Duan, L.S.; Tan, W.M.; Zhang, M.C.; Li, Z.H. Tillage practices affect biomass and grain yield through regulating root growth, root-bleeding sap and nutrients uptake in summer maize. Field Crop. Res. 2014, 157, 89-97. [CrossRef]

19. Chen, X.C.; Zhang, J.; Chen, Y.L.; Li, Q.; Chen, F.J.; Yuan, L.X.; Mi, G.H. Changes in root size and distribution in relation to nitrogen accumulation during maize breeding in China. Plant. Soil 2013, 374, 121-130. [CrossRef]

20. Li, C.S.; Li, J.G.; Tang, Y.L.; Wu, X.L.; Wu, C.; Huang, G.; Zeng, H. Stand establishment, root development and yield of winter wheat as affected by tillage and straw mulch in the water deficit hilly region of southwestern China. J. Integr. Agric. 2016, 15, 1480-1489. [CrossRef]

21. Xu, X.; Pang, D.W.; Chen, J.; Luo, Y.L.; Zheng, M.J.; Yin, Y.P.; Li, Y.X.; Li, Y.; Wang, Z.L. Straw return accompany with low nitrogen moderately promoted deep root. Field Crop. Res. 2018, 221, 71-80. [CrossRef]

22. Svoboda, P.; Haberle, J. The effect of nitrogen fertilization on root distribution of winter wheat. Plant. Soil Environ. 2006, 52, 308-313. [CrossRef]

23. Feng, G.Z.; Zhang, Y.J.; Chen, Y.L.; Li, Q.; Chen, F.J.; Gao, Q.; Mi, G.H. Effects of nitrogen application on root length and grain yield of rain-fed maize under different soil types. Agron. J. 2016, 108, 1656. [CrossRef]

24. Pedersen, A.; Zhang, K.; Thorup-Kristensen, K.; Jensen, L.S. Modelling diverse root density dynamics and deep nitrogen uptake-A simple approach. Plant. Soil 2009, 326, 493-510. [CrossRef]

25. Trachsel, S.; Kaeppler, S.M.; Brown, K.M.; Lynch, J.P. Maize root growth angles become steeper under low N conditions. Field Crop. Res. 2013, 140, 18-31. [CrossRef]

26. Thorup-Kristensen, K.; Salmerón, C.M.; Loges, R. Winter wheat roots grow twice as deep as spring wheat roots, is this important for $\mathrm{N}$ uptake and $\mathrm{N}$ leaching losses? Plant. Soil 2009, 322, 101-114. [CrossRef]

27. Lynch, J.P. Steep, cheap and deep: An ideotype to optimize water and $\mathrm{N}$ acquisition by maize root systems. Ann. Bot. 2013, 112, 347-357. [CrossRef]

28. Peng, Y.F.; Niu, J.F.; Peng, Z.P.; Zhang, F.S.; Li, C.J. Shoot growth potential drives N uptake in maize plants and correlates with root growth in the soil. Field Crop. Res. 2010, 115, 85-93. [CrossRef]

29. Yan, H.F.; Shang, A.X.; Peng, Y.F.; Yu, P.; Li, C.J. Covering middle leaves and ears reveals differential regulatory roles of vegetative and reproductive organs in root growth and nitrogen uptake in maize. Crop. Sci. 2011, 51, 265-272. [CrossRef]

30. Ogawa, A.; Kawashima, C.; Yamauchi, A. Sugar accumulation along the seminal root axis, as affected by osmotic stress in maize: A possible physiological basis for plastic lateral root development. Plant. Prod. Sci. 2015, 8, 173-180. [CrossRef]

31. Hirel, B.; Le Gouis, J.; Ney, B.; Gallais, A. The challenge of improving nitrogen use efficiency in crop plants: Towards a more central role for genetic variability and quantitative genetics within integrated approaches. J. Exp. Bot. 2007, 58, 2369-2387. [CrossRef] [PubMed]

32. Niu, J.F.; Peng, Y.F.; Li, C.J.; Zhang, F.S. Changes in root length at the reproductive stage of maize plants grown in the field and quartz sand. J. Plant. Nutr. Soil Sci. 2010, 173, 306-314. [CrossRef]

33. Gallais, A.; Coque, M. Genetic variation and selection for nitrogen use efficiency in maize: A synthesis. Maydica 2005, 50, 531-537.

34. Gao, K.; Chen, F.J.; Yuan, L.X.; Zhang, F.S.; Mi, G.H. A comprehensive analysis of root morphological changes and nitrogen allocation in maize in response to low nitrogen stress. Plant. Cell Environ. 2015, 38, 740-750. [CrossRef]

35. Blake, G.; Hartage, K. Methods of Soil Analysis, Part. 1; Macmillan: New York, NY, USA, 1986. 
36. Joseph, G.; Henry, H.A.L. Soil nitrogen leaching losses in response to freeze-thaw cycles and pulsed warming in a temperate old field. Soil Biol. Biochem. 2008, 40, 1947-1953. [CrossRef]

37. Dong, Q.G.; Yang, Y.C.; Yu, K.; Feng, H. Effects of straw mulching and plastic film mulching on improving soil organic carbon and nitrogen fractions, crop yield and water use efficiency in the Loess Plateau, China. Agric. Water Manag. 2018, 201, 133-143. [CrossRef]

38. Nelson, D.W.; Somers, L.E. Determination of total nitrogen in plant material. Agron. J. 1973, 65, $109-112$. [CrossRef]

39. Wang, T.C.; Wei, L.; Wang, H.Z.; Ma, S.C.; Ma, B.L. Responses of rainwater conservation, precipitation-use efficiency and grain yield of summer maize to a furrow-planting and straw-mulching system in northern China. Field Crop. Res. 2011, 124, 223-230. [CrossRef]

40. Dal Ferro, N.; Sartori, L.; Simonetti, G.; Berti, A.; Morari, F. Soil macro-and microstructure as affected by different tillage systems and their effects on maize root growth. Soil Tillage Res. 2014, 140, 55-65. [CrossRef]

41. Malhi, S.S.; Nyborg, M.; Solberg, E.D.; McConkey, B.; Dyck, M.; Puurveen, D. Long-term straw management and $\mathrm{N}$ fertilizer rate effects on quantity and quality of organic $\mathrm{C}$ and $\mathrm{N}$ and some chemical properties in two contrasting soils in Western Canada. Biol. Fert. Soils 2011, 47, 785-800. [CrossRef]

42. Yadvinder, S.; Gupta, R.K.; Jagmohan, S.; Gurpreet, S.; Gobinder, S.; Ladha, J.K. Placement effects on rice residue decomposition and nutrient dynamics on two soil types during wheat cropping in rice-wheat system in northwestern India. Nutr. Cycl. Agroecosys. 2010, 88, 471-480. [CrossRef]

43. Meek, B.D.; Carter, D.L.; Westermann, D.T.; Wright, J.L.; Peckenpaugh, R.E. Nitrate leaching under furrow irrigation as affected by crop sequence and tillage. Sci. Soc. Am. J. 1995, 59, 204-210. [CrossRef]

44. You, D.B.; Tian, P.; Sui, P.X.; Zhang, W.K.; Yang, B.; Qi, H. Short-term effects of tillage and residue on spring maize yield through regulating root-shoot ratio in Northeast China. Sci. Rep. 2017, 7, 13314. [CrossRef] [PubMed]

45. Ren, B.Z.; Li, X.; Dong, S.T.; Liu, P.; Zhao, B.; Zhang, J.W. Soil physical properties and maize root growth under different tillage systems in the North China Plain. Crop. J. 2018, 6, 669-676. [CrossRef]

46. Schneider, F.; Don, A.; Hennings, I.; Schmittmann, O.; Seidel, S.J. The effect of deep tillage on crop yield—What do we really know? Soil Tillage Res. 2017, 174, 193-204. [CrossRef]

47. Brennan, J.; Hackett, R.; McCabe, T.; Grant, J.; Fortune, R.A.; Forristal, P.D. The effect of tillage system and residue management on grain yield and nitrogen use efficiency in winter wheat in a cool Atlantic climate. Eur. J. Agron. 2014, 54, 61-69. [CrossRef]

48. Chen, Y.L.; Xiao, C.X.; Wu, D.L.; Xia, T.T.; Chen, Q.W.; Chen, F.J.; Yuan, L.X.; Mi, G.H. Effects of nitrogen application rate on grain yield and grain nitrogen concentration in two maize hybrids with contrasting nitrogen remobilization efficiency. Eur. J. Agron. 2015, 62, 79-89. [CrossRef]

49. Shi, Z.L.; Jing, Q.; Cai, J.; Jiang, D.; Cao, W.X.; Dai, T.B. The fates of ${ }^{15} \mathrm{~N}$ fertilizer in relation to root distributions of winter wheat under different N splits. Eur. J. Agron. 2012, 40, 86-93. [CrossRef]

50. Gallais, A.; Coque, M.; Le Gouis, J.; Prioul, J.L.; Hirel, B.; Quilléré, I. Estimating the proportion of nitrogen remobilization and of postsilking nitrogen uptake allocated to maize kernels by nitrogen-15 labeling. Crop. Sci. 2007, 47, 685. [CrossRef]

(C) 2020 by the authors. Licensee MDPI, Basel, Switzerland. This article is an open access article distributed under the terms and conditions of the Creative Commons Attribution (CC BY) license (http://creativecommons.org/licenses/by/4.0/). 